NOTE ON THE OCCURRENCE AND CONSTITUTION OF LIPÖID MATERIAL IN DIABETIC BLOOD

By FRED. P. WILSON, M.D. (Liverpool), Stopford-Taylor Research Fellow, University of Liverpool, AND OWEN T. WILLIAMS, M.D., B.Sc. (London), Medical Registrar to the Liverpool Royal Infirmary.

From the Bio-Chemical Laboratory, University of Liverpool.

(Received October 29th, 1906)

The condition known as Lipaemia, occurring in Diabetes, has hitherto not been regarded as a common one, and its presence has usually been regarded as of serious significance. During the course of some observations on the alkalinity of the blood, one of us (F.P.W.) had occasion to take samples from six cases of Diabetes Mellitus. This blood, and that in the additional cases, was collected in Wright's capsules.

Almost immediately after withdrawal from the patient the blood in five of the cases appeared opalescent, and in one there separated out a white purulent-looking material, which from mixture with red corpuscles presented an appearance like crushed strawberries and cream.

As most of these cases had been improving under treatment, and showed no signs of coma, we determined to investigate the subject further.

Accordingly, we have examined the blood of fifteen cases of Diabetes, and in ten the above condition was present in varying degree.

One of the series, Case XII, had only a temporary glycosuria.

Most of the cases showed only a semi-translucent opalescent appearance. This is easily distinguished, once it has been observed, from the fat-laden serum which separates out from normal blood after a meal of fat. The difference is still more marked after centrifugalisation; the former retaining its opalescent character, the latter separating to yield clear serum.

The condition seemed to vary in degree from time to time, and in three cases disappeared entirely. Two cases in which it was absent at first showed it later. 
The patients were all adults except Case IX, a boy aged twelve years.

Cases I to XII were in the Royal Infirmary, and Cases XIII to XV in Mill Road Infirmary, Liverpool.

The following Table shows the conditions under which the presence or absence of the lipaemia occurred :-

\begin{tabular}{|c|c|c|c|c|c|c|c|c|c|}
\hline $\begin{array}{l}\text { Number } \\
\text { of } \\
\text { Case }\end{array}$ & $\begin{array}{l}\text { Initials } \\
\text { of } \\
\text { Patient. }\end{array}$ & Date. & Diet. & $\begin{array}{l}\text { Presence } \\
\text { of } \\
\text { Lipaemia. }\end{array}$ & $\begin{array}{l}\text { Sugar } \\
\text { per } \\
\text { diem. }\end{array}$ & Acetone. & $\begin{array}{l}\text { Di-acetic } \\
\text { Acid. }\end{array}$ & Treatment. & $\begin{array}{l}\text { Fat in } \\
\text { Diet. }\end{array}$ \\
\hline I & P. $\mathrm{McC}$. & April 3 & Diabetic & + & 5,700 & + & + & $\begin{array}{l}\text { Duodenal Extract } \\
\text { Phenazone }\end{array}$ & + \\
\hline II & J. 0. & April 3 & Diabetic & + & 2,800 & + & + & $\begin{array}{l}\text { Duodenal Extract } \\
\text { Antipyrin }\end{array}$ & + \\
\hline III & E. $B$. & April 3 & Diabetic & + & 8,346 & + & + & Nil & + \\
\hline IV & L. W. & May Io & Diabetic & + & 8,545 & + & ++ & $\begin{array}{c}\text { Duodenal Extract } \\
\text { Antipyrin }\end{array}$ & + \\
\hline v & S. S. & May Io & Ordinary & - & 2,612 & + & + & Nil & \\
\hline VI & G. C. & July 6 & Ordinary & + & 4,219 & + & + & Nil & \\
\hline \multirow[t]{3}{*}{ VII } & W. M. & April 3 & Diabetic & + & - & + & + & Alkalies & + \\
\hline & & May 8 & Diabetic & + & 7,788 & + & + & Duodenal Extract & + \\
\hline & & July 4 & $\begin{array}{l}\text { Diabetic and } \\
\text { Potatoes }\end{array}$ & + & 3,967 & + & + & Duodenal Extract & \\
\hline \multirow[t]{2}{*}{ VIII } & W. Y. & May Io & Diabetic & + & 8,194 & + & + & & \\
\hline & & July 12 & Diabetic & + & 3,534 & + & + & $\begin{array}{l}\text { Duodenal Extract } \\
\text { Alkalies }\end{array}$ & + \\
\hline \multirow[t]{3}{*}{ IX } & T. M. & April 3 & Diabetic & - & 3,420 & - & - & Nil & + \\
\hline & & May 8 & Diabetic & + & $4, \infty 00$ & + & + & $\begin{array}{c}\text { Duodenal Extract- } \\
\mathrm{HCl}\end{array}$ & + \\
\hline & & July 7 & Diabetic & + & 4,864 & + & + & Duodenal Extract & + \\
\hline \multirow[t]{2}{*}{$\mathbf{x}$} & J. F. & May 22 & Ordinary & + & 6,714 & + & $\underset{\text { slight }}{+}$ & Nil & \\
\hline & & July 7 & Diabetic & - & $\begin{array}{l}\text { not esti- } \\
\text { mated }\end{array}$ & - & - & $\begin{array}{l}\text { Duodenal Extract- } \\
\mathrm{HCl}\end{array}$ & + \\
\hline \multirow[t]{2}{*}{ XI } & M. P. & April 3 & Diabetic & + & $\mathrm{I}, 34 \mathrm{I}$ & + & + & $\begin{array}{l}\text { Duodenal Extract } \\
\text { Phenazone }\end{array}$ & + \\
\hline & & July I 2 & Diabetic & - & & + & + & & + \\
\hline \multirow[t]{2}{*}{ XII } & A. B. & May 8 & Diabetic & - & Present & - & - & Nil & little \\
\hline & & May 22 & Diabetic & - & & - & - & Duodenal Extract & little \\
\hline XIII & “B," 2 & April 8 & - & - & Present & - & - & & little \\
\hline XIV & “B," 3 & April 8 & - & - & Present & - & - & & little \\
\hline \multirow[t]{2}{*}{$\mathrm{XV}$} & “D,” 3 & July 2 & - & - & Present & - & - & & little \\
\hline & & July 7 & - & - & & - & - & & much \\
\hline
\end{tabular}




\section{Notes to THE TABLE}

Relationship to Diet.-Most of the cases we examined had been on diabetic diet for some time, but three had the condition on admission to the Hospital. Some cases had the fat in their diet considerably reduced, but it made no apparent difference to the blood. Cases XIII and XIV were not lipaemic when their blood was examined, and, unfortunately, died two or three days later. Case XV, also not lipaemic, was allowed a fat-rich-diet, but five days later the lipaemic condition was absent, and has remained so. It is obvious that drugs did not produce the condition, as some of the patients had received no drugs at all. There is no apparent relation between the condition and the amount of sugar excreted.

Acetone and Di-acetic Acid.-The Table shows a very striking relation between the lipaemic condition and the presence of acetone and di-acetic acid in the urine. Cases $\mathrm{V}$ and XI (on one occasion), which are exceptions, were extremely ill when the observations were made, and it is interesting to note that in the severest cases the blood condition was absent. Case IX is instructive in that it showed at first the absence of acetone and di-acetic acid, and also of lipaemia, while later these conditions occurred concurrently. For this reason we decided to inquire into the effect of fat in the food on the lipaemia and on the substances in the urine. Case XII was kept on a fat-rich-diet for eleven days, and the amount of acetone estimated. Then fat was removed as completely as possible from the diet for six days, and the effect noted. Unfortunately, during the latter part of the investigation the patient surreptitiously obtained some potatoes, but, so far as we could ascertain, no fat.

The following amounts of acetone were excreted per diem :-

$$
\begin{aligned}
& \begin{array}{lllllllllll}
\text { Ist day } & \ldots & \ldots & \mathrm{I}^{\circ} 048 & \text { grms. } & 6 \text { th } & \text { day } & \ldots & \ldots & 7008 & \text { grms. }
\end{array}
\end{aligned}
$$

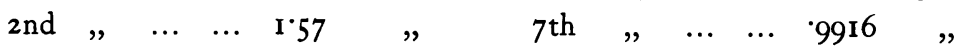

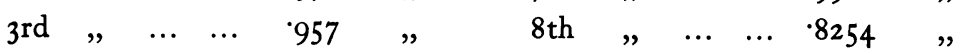

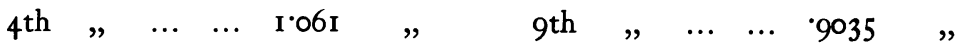

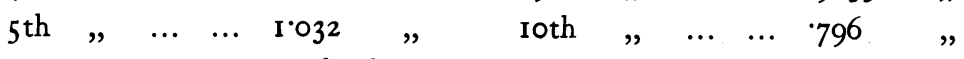

$$
\begin{aligned}
& \text { II th day } \ldots \quad \ldots \quad 796 \text { grms. }
\end{aligned}
$$

On the Fat-free Diet :-

$$
\begin{array}{llllllllllll}
\text { 12th } & \text { day } & \ldots & \ldots & \text { I.4054 } & \text { grms. } & \text { I5th } & \text { day } & \ldots & \ldots & \text { I.417 } & \text { grms. } \\
\text { I3th } & \ldots & \ldots & \ldots & \text { I.1708 } & , & \text { 16th } & , & \ldots & \ldots & \text { I.298 } & , \\
\text { I4th } & \ldots & \ldots & \ldots & \text { I.1 } 88 & , & \text { I7th } & , & \ldots & \ldots & \text { I.234 } & ,
\end{array}
$$

It is thus evident that the acetone did not diminish with the cutting off of the fat. The blood condition also was unaltered.

A second observation to the same effect made on Case VI, under more stringent conditions, yielded similar results. 
The Nature of the Lipöid Material

Microscopical Examination.-The material was found to consist of minute globules, smaller than those of milk, in a state of movement resembling the Brownian movement.

Chemical Examination.-The blood used for this purpose was from Case X. It was one of the less marked cases, merely showing the opalescent appearance noted above. Sir James Barr, under whose care the patient was, kindly obtained for us 28.649 grams of blood. This was extracted with alcohol and ether, the weight of the total extract when dried being I per cent. of the whole blood.

An analysis of this extract showed it to contain-

I8.9 per cent. of free fatty acid,

$60 \cdot 2$ per cent. of combined fatty acid,

Both estimated as oleic acid.

The unsaponifiable matter having been separated, pure crystalline cholesterin was isolated from it, the amount being I $8 \cdot 1$ per cent. of the ethereal extract.

In two of the most marked cases cholesterin was isolated from about I c.c. of the blood, and recognised microscopically. The fatty acids gave an iodine value of 27 , which shows that the bulk of the fatty acids present were saturated. Dr. H. E. Roaf, in a case of Lipaemia from the post-mortem room, recently found an uncrystallisable material giving the reactions of cholesterin, and which was probably one of its isomers.

B. Fischer ${ }^{1}$ in one case of Lipaemia with coma found the blood to be of the same nature, the lipöid material being mainly composed of an ester of cholesterin, and also that the fatty acids present were saturated.

It is usually accepted that the probabilities are that saturated fatty acids come from the body-fat, whereas the unsaturated fatty-acids are more likely derived from the food-fat.

It is, therefore, probable that the fatty-acids in lipaemia are drawn from the tissue fats. 
Our observations tend to confirm this, as in the severe cases, where most of the body fat had been used up, the blood did not show the condition of lipaemia.

In conclusion we should like to draw attention to the following deductions :-

I. That the occurrence of the so-called lipaemia is not so rare a condition, nor of such grave significance, as has formerly been supposed.

2. That it is in all probability an expression of an abnormal metabolism of fat; as the character of the ester in the blood and its presence concurrently with acetone and di-acetic acid in the urine would show. This would explain the danger which is said to occur from sudden withdrawal of all carbohydrates from a diabetic diet, for the patient has then to draw upon his tissue fat, and in so doing would accentuate this abnormal metabolism.

We have to thank Sir James Barr, Dr. Bradshaw, Dr. Abram, and Dr. Raw for the use of their cases, and also Professor Benjamin Moore for his kindness and advice in his laboratory, where the work was carried out under his direction. 